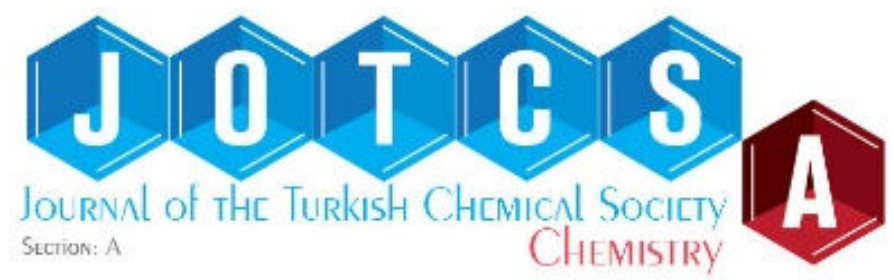

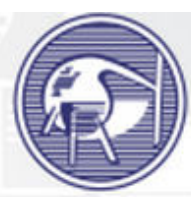

TURKISH CHEMICAL SOCIETY

(This article was presented to the 28th National Chemistry Congress and submitted to JOTCSA as a full manuscript)

\title{
Determination of Cocaine and Benzoylecgonine in Biological Matrices by HPLC and LC-MS/MS
}

\author{
Zinar Pinar Gumus ${ }^{1 *}$, Veysel Umut Celenk ${ }^{2}$, Emine Güler ${ }^{1,4}$, Bilal Demir ${ }^{4}$, Hakan Coskunol ${ }^{1,3}$, \\ Suna Timur ${ }^{1,4}$ \\ ${ }^{1}$ University of Ege, Institute on Drug Abuse, Toxicology and Pharmaceutical Sciences, 35040, \\ İzmir, Turkey \\ 2University of Ege, Faculty of Science, Department of Chemistry, 35100, İzmir, Turkey. \\ 3 University of Ege, Faculty of Medicine, Department of Psychiatry, 35040, İzmir, Turkey \\ ${ }^{4}$ University of Ege, Faculty of Science, Department of Biochemistry, 35100, İzmir, Turkey.
}

\begin{abstract}
Cocaine is a powerfully addictive illicit drug. Cocaine abuse and addiction continue to increase in the world. Most analytical tests for the detection of cocaine use include the analysis of the metabolite, benzoylecgonine, in the urine. Benzoylecgonine is a major urinary metabolite of cocaine. Generally, the most common biologic matrices used for the analysis of cocaine contain the urine and blood however saliva was also added as a matrix in this study. Practical, quick, reliable, precise and accurate, reproducible analytical methods have been developed and validated for cocaine and benzoylecgonine. In addition, these chromatographic techniques were used as both initial test and confirmatory. The validated chromatographic method was successfully applied to the analysis of cocaine and benzoylecgonine compounds in synthetic matrix. Confirmation analyses were made by LC-MS/MS to support reliability of HPLC results. As a result of this study, it can be claimed that HPLC could be a good alternative for the analyses of various biological matrices in forensic studies.
\end{abstract}

Keywords: Cocaine; Benzoylecgonine; HPLC; LC-MS/MS.

Submitted: July 24, 2016. Revised: September 23, 2016. Accepted: October 07, 2016.

Cite this: Gumus Z, Celenk V, Guler E, Demir B, Coskunol H, Timur S. Determination of Cocaine and Benzoylecgonine in Biological Matrices by HPLC and LC-MS/MS. JOTCSA. $2016 ; 3(3): 535-50$.

DOI: $10.18596 /$ jotcsa.82665.

*Corresponding author. E-mail: z.pinar.gumus@gmail.com. Phone: +90 2323901600. Fax: +902323901614. 
Gumus et al., JOTCSA. 2016;3(3): 535-550.

\section{INTRODUCTION}

Cocaine is a strongly addictive stimulant drug made from the leaves of the coca plant. Cocaine is directly affected the central nervous system (CNS) [1]. Cocaine was labelled as the drug of the 1980 s and 1990 s because of its widespread popularity and use during that period. However, cocaine is not a new drug. Actually, it is one of the oldest known psychoactive substances [2]. Cocaine consist in illicit samples as the cocaine salt or as the cocaine base. The use of illicit drugs has negative effect on the health of drug users in addition to this drugs have been affected economic and social costs to the community [3]. Cocaine has a lot of health effects, which are constriction of blood vessels, increase of bodily temperature, heart rate, blood pressure, abdominal pain, nausea, headaches, restlessness, and anxiety $[4,5]$. Injecting cocaine can do strong allergic reactions and increased risk for HIV, hepatitis $C$, and other blood-spread diseases [1]. According to United Nations Office on Drugs and Crime (UNODC) World Drug Report, it is estimated that one-twentieth of people between the ages of 15 and 64 used illicit drugs within the last year [6]. In addition, there are 14.9 million cocaine users according to the last European Monitoring Centre for Drugs and Drug Addiction (EMCDDA) annual report [7].

The most common form of illicit cocaine is the white crystalline, highly water soluble powder. Cocaine metabolites such as norcocaine, benzoylecgonine (BE) and ecgonine methylester, etc., contribute to the toxicity of cocaine (metabolite). The major metabolic pathways of cocaine metabolism involve 1) human carboxylesterase-1 (hCE-1)-mediated and spontaneous chemical hydrolysis of cocaine to BE and 2) pseudocholinesterase-2 and human carboxylesterase-2 (hCE2)-mediated hydrolysis of cocaine to ecgonine methyl ester [8]. BE is a major urinary metabolite of cocaine.

Among the worldwide addiction problems, cocaine addiction is a frequent and severe public health problem; therefore, quick, easy, and reliable methods are required to determine of cocaine and $\mathrm{BE}$ in the biological matrix for medical and toxicology laboratories [9]. Most chromatographic methods for the detection of cocaine use involve the analysis of the metabolite, $\mathrm{BE}$, in the biological matrix such as urine, serum and saliva. Liquid chromatography is a very powerful tool increasingly used in analytical laboratories [10]. Cocaine and its metabolite BE can be separated by using chromatographic methods from other analytes and impurities. Therefore, liquid chromatographic techniques were used in this study for better determination of cocaine and also chromatographic techniques are very specific, minimizes false positives and false negatives, very sensitive, detects low levels of drug, and quantitative testing methods [11-13]. Cut off concentrations of cocaine and BE were identified by Substance Abuse and Mental Health Services Administration (SAMSHA) as $150 \mathrm{ng} / \mathrm{mL}$ and $100 \mathrm{ng} / \mathrm{mL}$ for initial test and confirmatory test, respectively [14]. Generally, the most common biologic samples used for the analysis of 
Gumus et al., JOTCSA. 2016;3(3): 535-550.

RESEARCH ARTICLE

cocaine involve the blood and urine however saliva was also added as a matrix in this study. Practical, quick, reliable, precise and accurate, reproducible analytical methods have been developed and validated for cocaine and benzoylecgonine. In addition, these chromatographic techniques were used both initial test and confirmatory test for forensic toxicology. After analytical method validation, its application to biological samples was tested by using synthetic urine, serum and saliva. Confirmation analyses were made by LC-MS/MS to support reliability of HPLC results.

\section{MATERIALS AND METHODS}

Standards, samples, chemicals, and reagentsAll chemicals and reagents was obtained from Merck, Sigma Aldrich and LabScan. Ultrapure water was produced by purification system Milli-Q from Millipore Corporation. The analytical standard of cocaine and benzoylecgonine were obtained from Cerillant.

\section{Standard solutions}

Stock solutions of cocaine and benzoylecgonine were prepared separately in methanol at concentrations of $100 \mu \mathrm{g} / \mathrm{mL}$. All stock solutions were stored at $-20{ }^{\circ} \mathrm{C}$. Different concentrations of working solutions for liquid chromatography analysis were diluted from this solution with methanol.

\section{Sample preparation}

Synthetic urine, saliva, and serum samples were prepared according to the Wilsenach et al., Gal et al., and Bahadir et al. and the compositions of synthetic urine, saliva, and serum solutions are given in supplementary material SM-1 [15-17]. The synthetic biological matrices were spiked with standard solutions of Cocaine and $B E$ and then filtered before injection into the chromatographic system. The samples were prepared freshly prior to chromatographic analyses. Cocaine or BE spiked samples were injected to the chromatography system without needing any extraction procedures.

\section{HPLC-DAD instrumentation and conditions}

The chromatographic separation and analysis of cocaine and BE were carried out using HPLC (Agilent) combined DAD detector and the elution of the compounds in the chromatogram was 
Gumus et al., JOTCSA. 2016;3(3): 535-550.

RESEARCH ARTICLE

performed by an Eclipse XDB-C18 column (5.0 $\mu \mathrm{m}$ particle size, $4.6 \times 150 \mathrm{~mm})$. Instrument parameters was given in Table 1 for the Cocaine and BE analyses.

Table 1. HPLC instrument conditions of cocaine and BE

\begin{tabular}{|c|c|c|}
\hline $\begin{array}{l}\text { HPLC Instrument } \\
\text { Conditions }\end{array}$ & COCAINE & BE \\
\hline Mobile Phase & $\begin{array}{l}\text { Isocratic; }(A) \mathrm{pH} 6.0 \\
\text { phosphate buffer (B) } \\
\text { acetonitrile }(40: 60, \mathrm{v}: \mathrm{v})\end{array}$ & $\begin{array}{l}\text { Isocratic; }(A) 0.2 \%(\mathrm{v} / \mathrm{v}) \\
\text { aqueous phosphoric acid and } \\
\text { (B) acetonitrile }(80: 20, \mathrm{v}: \mathrm{v})\end{array}$ \\
\hline Wavelength & $235 \mathrm{~nm}$ & $225 \mathrm{~nm}$ \\
\hline Column Temperature & $40^{\circ} \mathrm{C}$ & $35^{\circ} \mathrm{C}$ \\
\hline Flow rate & $1.0 \mathrm{~mL} / \mathrm{min}$ & $1.0 \mathrm{~mL} / \mathrm{min}$ \\
\hline Injection Volume & $20 \mu \mathrm{L}$ & $20 \mu \mathrm{L}$ \\
\hline
\end{tabular}

\section{LC-MS/MS instrumentation and conditions}

The LC-MS/MS system consisted of a Waters Acquity UPLC instrument using an Acquity UPLC BEH C18 column $(1.7 \mu \mathrm{m}, 50 \mathrm{~mm} \times 2.1 \mathrm{~mm}$ i.d.). The UPLC was connected to Waters TQD Mass Spectrometer. Tandem mass spectrometer was equipped with an electrospray ionization (ESI) and operated in positive-ion mode. The scanned data was collected in single ion monitoring mode (SIM). Nitrogen and argon were used as cone and collision gases, respectively. LC-MS/MS instrument parameters for the analysis of Cocaine and BE were shown in Table 2. 
Gumus et al., JOTCSA. 2016;3(3): 535-550.

Table 2. LC-MS/MS instrument conditions of Cocaine and BE

\begin{tabular}{|c|c|c|}
\hline $\begin{array}{l}\text { LC-MS/MS Instrument } \\
\text { Conditions }\end{array}$ & COCAINE & BE \\
\hline \multirow[t]{4}{*}{ Mobile Phase } & A) Water contains $0.1 \%$ & A) Water contains $0.1 \%$ \\
\hline & Acetic Acid & Acetic Acid \\
\hline & B) Acetonitrile contains 0.1 & B) Acetonitrile contains 0.1 \\
\hline & $\%$ Acetic Acid & $\%$ Acetic Acid \\
\hline Cone Voltage (V) & 35 & 30 \\
\hline Collision Voltage (V) & 25 & 30 \\
\hline Parent Ion/Daughter Ions $(\mathrm{m} / \mathrm{z})$ & $304 / 150,182 *$ & $290.3 / 105.3,168.3 *$ \\
\hline Dwell Time (s) & 0.01 & 0.01 \\
\hline Column Temperature $\left({ }^{\circ} \mathrm{C}\right)$ & 50 & 50 \\
\hline Desolvation Gas Temp. $\left({ }^{\circ} \mathrm{C}\right)$ & 350 & 350 \\
\hline Gas Flow Rate (L/h) & $500 \mathrm{~L} / \mathrm{h}$ & $500 \mathrm{~L} / \mathrm{h}$ \\
\hline Flow rate $(\mathrm{mL} / \mathrm{min})$ & 0.400 & 0.400 \\
\hline Injection Volume $(\mu \mathrm{L})$ & 5 & 5 \\
\hline
\end{tabular}

*Daughter ions were used as determinant ions. The others were used as control ions.

The Masslynx software version 4.1 was used in controlling the instruments, peak integration and calculation.

\section{Validation of the chromatographic methods}

The validation of the analytical procedures was carried out according to the International Conference on Harmonization Guidelines (ICH Q2B, validation of analytical procedures, methodology) [18]. According to these guidelines, the key parameters to assurance the acceptability of the performance of an analytical method are as follows: Linearity, sensitivity (limit of detection (LOD) and limit of quantification (LOQ)), precision and accuracy, selectivity.

\section{RESULTS AND DISCUSSION}

Several mobile phase systems were tested for developing liquid chromatographic method for determination of Cocaine and $\mathrm{BE}$. Mobile phase and related chromatographic conditions were chosen considering the smooth baseline, and peak response. 
Gumus et al., JOTCSA. 2016;3(3): 535-550.

RESEARCH ARTICLE

\section{Linearity of the analytical methods}

The linearity was studied through the external standardization method. To conduct this study, working standard solutions were prepared at five level of concentration for LC-MS/MS analyses and six levels of concentration for HPLC analyses with triplicate injections. The calibration curves were designed to investigate the correlation between the peak area $(y)$ and the injection concentration $(x ; n g / m L)$ of analytes. The linearity was expressed in terms of the correlation coefficient $\left(R^{2}\right)$. The results showed a good correlation between the peak areas and the concentration of chromatographic injections, with $\mathrm{R}^{2}$. The concentrations ranges, linear regression equations, correlation coefficient and retention times of analytes were given in Table 3.

Table 3. Linear regression equation, calibration curve and retention times of the analytical method.

\begin{tabular}{ccc}
\hline HPLC method & COCAINE & BE \\
\hline Linear Ranges $(\mathrm{ng} / \mathrm{mL})$ & $1.0-100$ & $50.0-7500$ \\
Linear Regression Equation & $\mathrm{y}=0.3453 \mathrm{x}-0.0154$ & $\mathrm{y}=0.0241 \mathrm{x}-0.0192$ \\
Correlation Coefficient & 0.9999 & 0.9999 \\
Retention Time $(\mathrm{min})$ & 2.09 & 2.67 \\
\hline LC-MS $/$ MS method & COCAINE & $\mathbf{B E}$ \\
\hline Linear Ranges $(\mathrm{ng} / \mathrm{mL})$ & $0.25-5.0$ & $1.0-25$ \\
Linear Regression Equation & $\mathrm{y}=854.18 \mathrm{x}+7.9587$ & $\mathrm{y}=91128 \mathrm{x}-275.52$ \\
Correlation Coefficient & 1.00 & 0.00 \\
Retention Time $(\mathrm{min})$ & 1.65 &
\end{tabular}

Both HPLC and LC/MS/MS methods have good correlation coefficient values in terms of linearity. Blank chromatograms for matrices could be seen in SM-3. HPLC chromatograms of cocaine and BE were shown in Figures 1 and 2. 
Gumus et al., JOTCSA. 2016;3(3): 535-550.

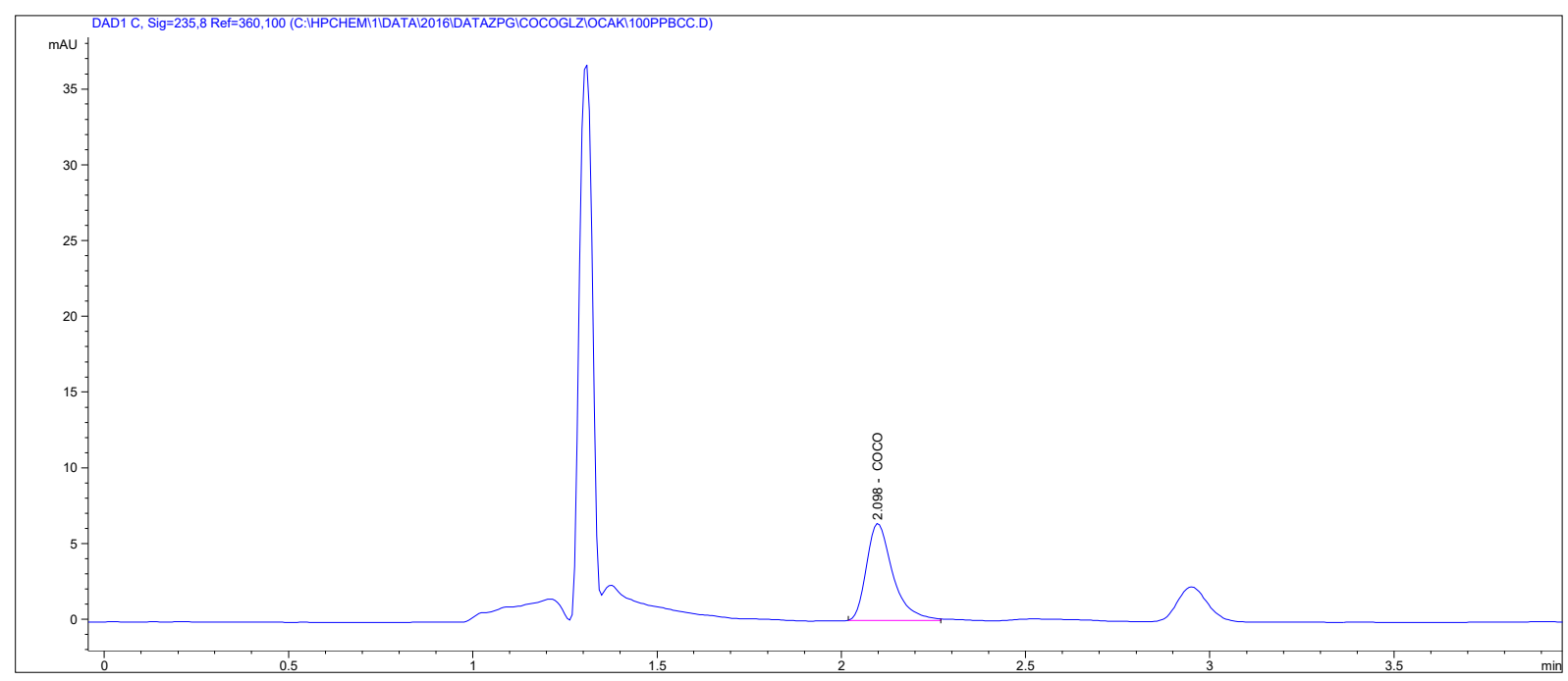

Figure 1. HPLC chromatogram of cocaine.

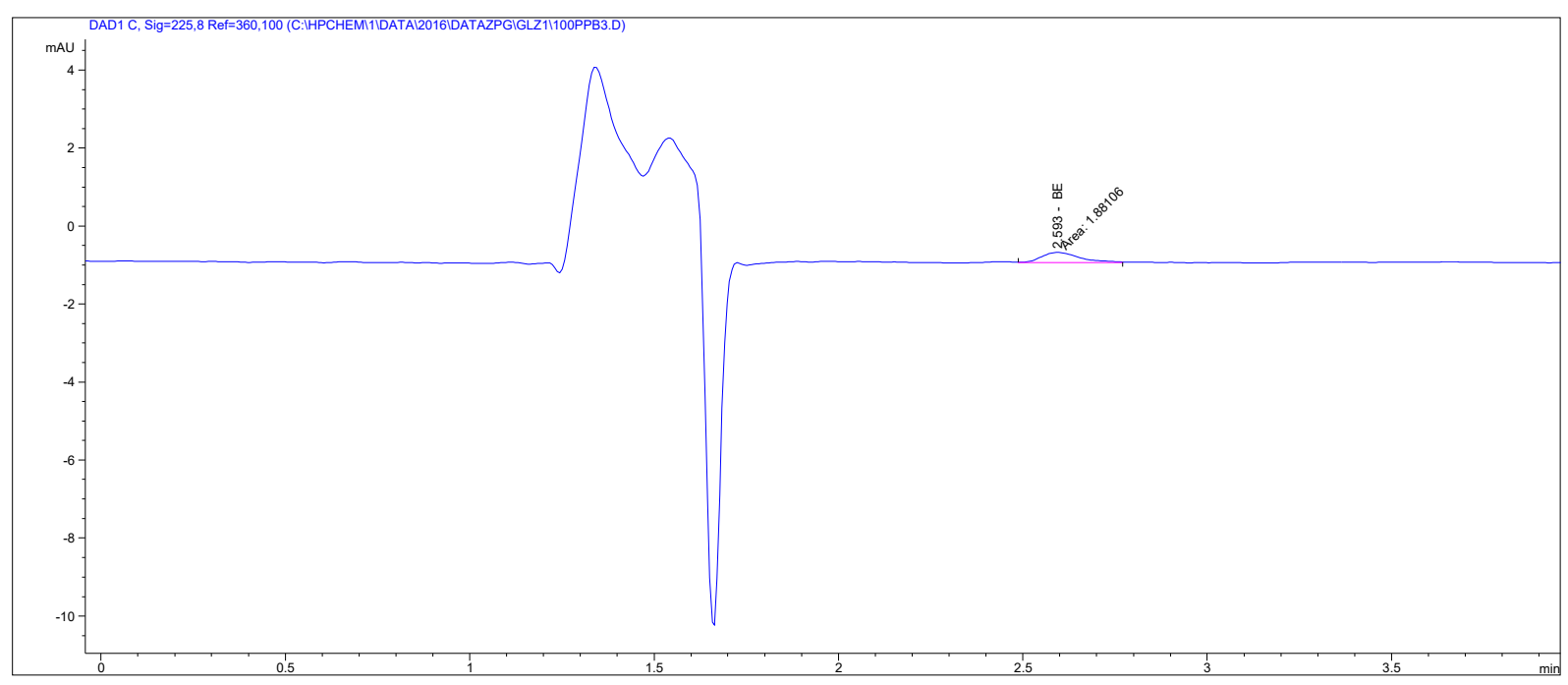

Figure 2. HPLC chromatogram of BE.

m/z 182 and m/z 150 ions chromatogram of cocaine was shown as in Figures 3 and 4. 


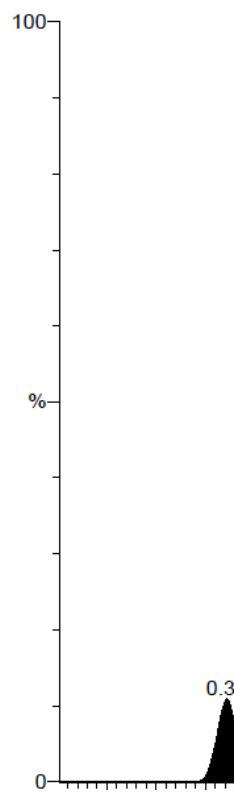

$304>182$
$1.165 e+005$ methyl (1R,2R,3S,5S)-3- (benzoyloxy)-8-methyl-8-azabicyclo[3.2.1] octane-2-carbo 1.65
2155 2155 1

Figure 3. LC-MS/MS chromatogram of cocaine for determinant ion m/z 182 .

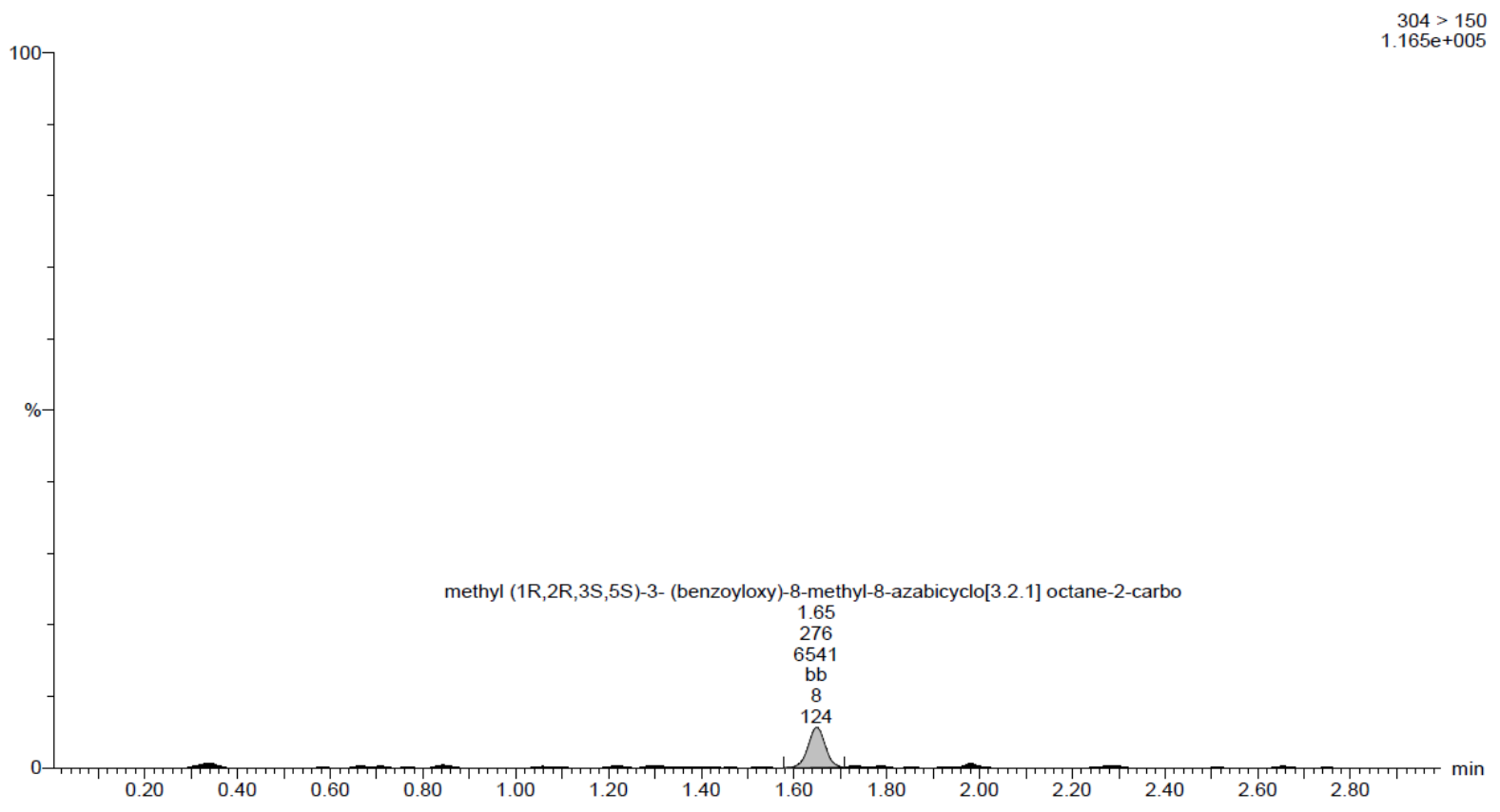

Figure 4. LC-MS/MS chromatogram of cocaine for control ion m/z 150 .

m/z 168.3 and m/z 105.3 ions chromatogram of BE was shown as in Figure 5 and 6. 


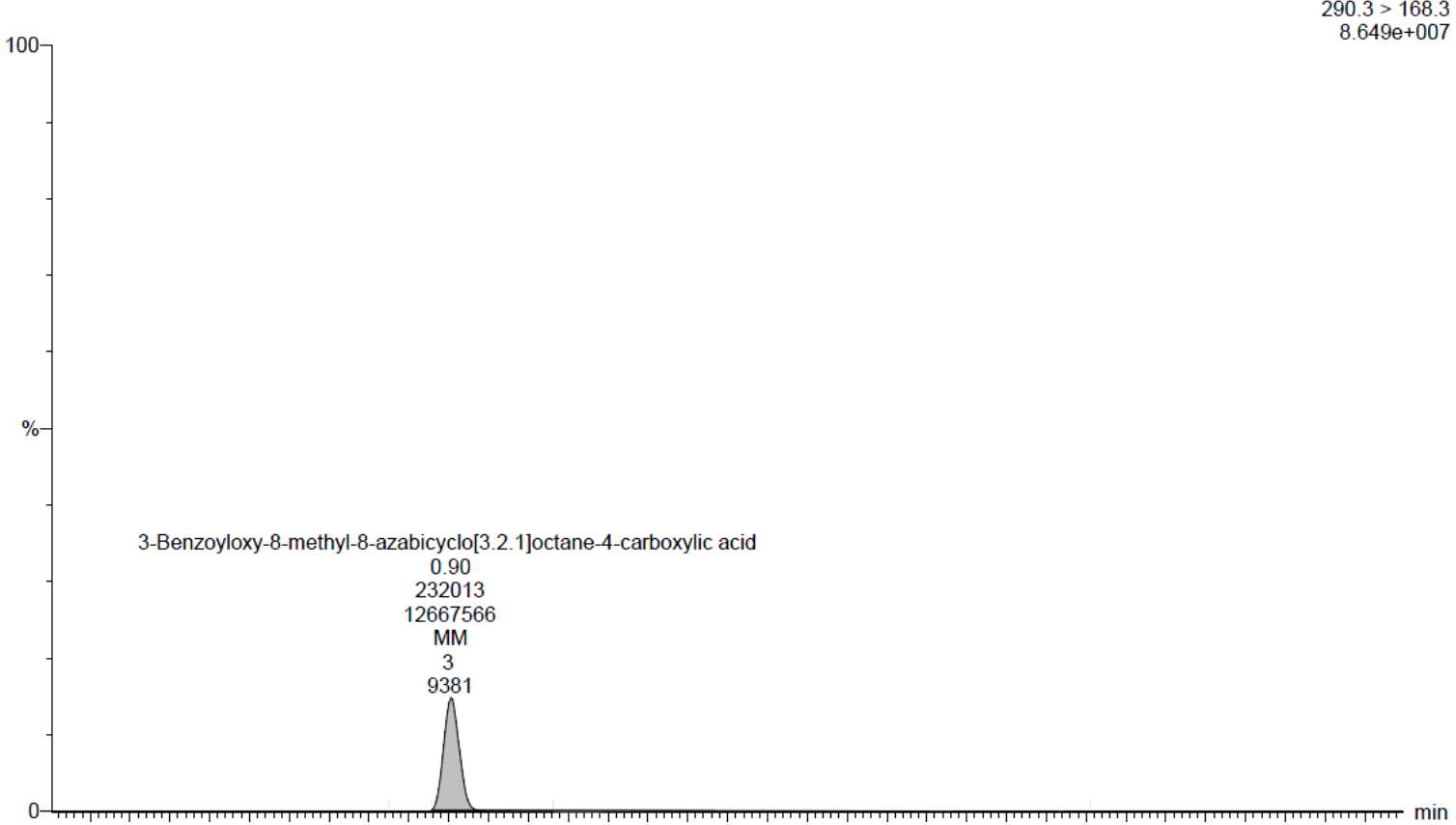

Figure 5. LC-MS/MS chromatogram of $B E$ for determinant ion $\mathrm{m} / \mathrm{z}$ 168.3.

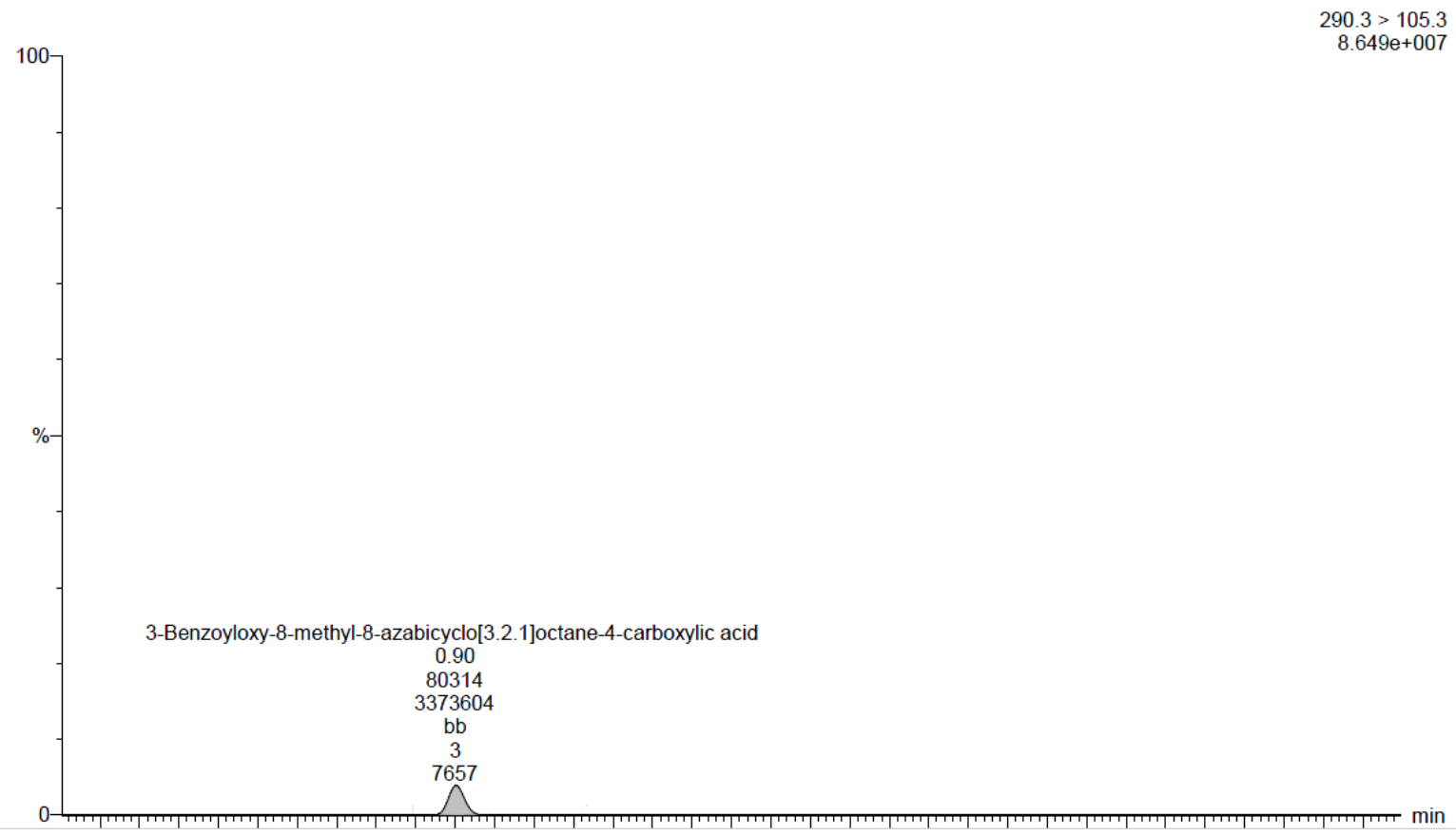

Figure 6. LC-MS/MS chromatogram of BE for control ion $\mathrm{m} / \mathrm{z}$ 105.3.

\section{Limits of detection (LOD) and quantification (LOQ)}

The limit of detection (LOD) and the limit of quantification (LOQ) for Cocaine and BE were analysed to evaluate the sensitivity of the methods. LOD and LOQ of the HPLC and LC-MS/MS 
Gumus et al., JOTCSA. 2016;3(3): 535-550.

RESEARCH ARTICLE

methods were estimated from the signal-to-noise ratio of about $3: 1$ and 10:1, respectively. LOD and LOQ values of Cocaine and BE were given in Table 4 for HPLC and LC-MS/MS methods.

Table 4. LOD and LOQ values of methods for COCAINE and BE.

\begin{tabular}{ccc}
\hline HPLC method & COCAINE & BE \\
\hline LOD $(\mathrm{ng} / \mathrm{mL})$ & 0.55 & 4.62 \\
LOQ $(\mathrm{ng} / \mathrm{mL})$ & 1.82 & 15.38 \\
\hline LC-MS/MS method & COCAINE & BE \\
\hline LOD $(\mathrm{ng} / \mathrm{mL})$ & 0.03 & 0.69 \\
LOQ $(\mathrm{ng} / \mathrm{mL})$ & 0.10 & 2.33 \\
\hline
\end{tabular}

Since these values are lower than SAMSHAs' cut off values, these chromatographic methods could be used to determine COCAINE and BE in the synthetic biological matrices successfully according to LOD and LOQ values.

\section{Precision of analytical methods}

The precision was evaluated using measurements of the injection repeatability of analytes. The repeatability was investigated using working standard solutions prepared at appropriate concentration levels. Cocaine and BE concentrations were $10 \mathrm{ng} / \mathrm{mL} ; 1.0 \mathrm{ng} / \mathrm{mL}$ and $500 \mathrm{ng} / \mathrm{mL}$ and $5.0 \mathrm{ng} / \mathrm{mL}$ for HPLC and LC-MS/MS, respectively. Peak areas and retention times were identified. The results were expressed as the Relative Standard Deviation of measurements (RSD\%).at six replicate injections as described in Table 5.

Table 5. Precision of HPLC and LC-MS/MS method.

\begin{tabular}{ccccc}
\hline HPLC method & Cocaine (Area) & BE (Area) & Cocaine (RT) & BE (RT) \\
\hline Mean & 3.382 & 13.817 & 2.098 & 2.673 \\
SD & 0.064 & 0.147 & 0.003 & 0.008 \\
RSD \% & 0.100 & 1.065 & 0.162 & 0.305 \\
\hline LC-MS/MS & Cocaine (Area) & BE (Area) & Cocaine (RT) & BE (RT) \\
\hline Mean & 868024 & 454252686 & 1.65 & 0.90 \\
SD & 1190 & 1917980 & 0.00 & 0.00 \\
RSD \% & 0.137 & 0.422 & 0.00 & 0.00 \\
\hline
\end{tabular}

According to RSD values of repeatability, these methods indicated good precision and RSD values which were under the $2 \%$. 
Gumus et al., JOTCSA. 2016;3(3): 535-550.

RESEARCH ARTICLE

\section{Accuracy of analytical methods}

The accuracy of the methods was evaluated on the basis of the spiked matrix recovery for each standard substance. The accuracy was expressed as the percentage of the amount recovered in the spiked sample compared to the standard concentrations.

A certain amount of Cocaine and BE standards was added to synthetic serum, saliva and urine samples and then analysed using the developed HPLC and LC-MS/MS methods. The recovery of each added standard substance was calculated by the following formula: recovery\% $=[(\mathrm{Cm}-$ $\mathrm{Cs}) /(\mathrm{Ca})] \times 100$, where $\mathrm{Cm}$ is the measured amount of the samples; Cs and Ca represent the mean value of the detected Cocaine and $\mathrm{BE}$ in synthetic biological samples and added standard substances, respectively.

Percent recovery values of Cocaine and BE were shown in Table 6 and Table 7 for HPLC and LCMS/MS methods in synthetic biological matrices.

Table 6. Recovery of HPLC method for urine, saliva, serum.

\begin{tabular}{cccc}
\hline $\begin{array}{c}\text { Added COCAINE } \\
\text { (ng/mL) }\end{array}$ & $\begin{array}{c}\text { Recovery (\%) } \\
\text { (Urine) }\end{array}$ & $\begin{array}{c}\text { Recovery (\%) } \\
\text { (Saliva) }\end{array}$ & $\begin{array}{c}\text { Recovery (\%) } \\
\text { (Serum) }\end{array}$ \\
\hline 1 & 80.46 & 42.48 & 71.69 \\
1 & 83.38 & 36.63 & 83.38 \\
1 & 77.53 & 39.56 & 77.53 \\
5 & 96.72 & 38.29 & 82.12 \\
5 & 93.80 & 39.46 & 87.37 \\
5 & 95.55 & 40.05 & 85.62 \\
10 & 97.44 & 40.47 & 92.18 \\
10 & 100.36 & 39.01 & 89.26 \\
10 & 97.15 & 43.10 & 84.88 \\
\hline Added BE & Recovery (\%) & Recovery (\%) & Recovery (\%) \\
(ng/mL) & (Urine) & (Saliva) & (Serum) \\
\hline 100 & 91.26 & 99.89 & 97.9 \\
100 & 90.24 & 98.37 & 102.9 \\
100 & 94.30 & 96.34 & 98.9 \\
500 & 92.16 & 102.41 & 100.4 \\
500 & 95.21 & 99.57 & 99.06 \\
500 & 95.41 & 98.05 & 97.94 \\
1000 & 91.21 & 95.52 & 99.58 \\
1000 & 96.08 & 98.11 & 100.09 \\
1000 & 99.84 & 93.44 & 99.94 \\
\hline
\end{tabular}


Gumus et al., JOTCSA. 2016;3(3): 535-550.

Table 7. Recovery of LC-MS/MS method for urine, saliva, serum.

\begin{tabular}{cccc}
\hline $\begin{array}{c}\text { Added Cocaine } \\
\text { (ng/ } \mathbf{m L})\end{array}$ & $\begin{array}{c}\text { Recovery (\%) } \\
\text { (Urine) }\end{array}$ & $\begin{array}{c}\text { Recovery (\%) } \\
\text { (Saliva) }\end{array}$ & $\begin{array}{c}\text { Recovery (\%) } \\
\text { (Serum) }\end{array}$ \\
\hline 0.3 & 85.2 & 50.7 & 94.7 \\
0.3 & 90.7 & 47.1 & 93.4 \\
0.3 & 90.3 & 55.0 & 97.6 \\
0.75 & 97.1 & 51.8 & 107.6 \\
0.75 & 103.6 & 59.1 & 102.8 \\
0.75 & 102.2 & 52.5 & 106.7 \\
1.50 & 91.1 & 78.5 & 101.4 \\
1.50 & 92.1 & 73.3 & 103.1 \\
1.50 & 101.4 & 85.2 & 100.1 \\
\hline Added BE & Recovery (\%) & Recovery (\%) & Recovery (\%) \\
(ng/mL) & (Urine) & (Saliva) & (Serum) \\
\hline 1.00 & 101.7 & 102.7 & 99.2 \\
1.00 & 96.7 & 100.4 & 99.0 \\
1.00 & 98.2 & 100.5 & 98.9 \\
2.50 & 91.9 & 101.0 & 101.3 \\
2.50 & 92.0 & 103.5 & 98.4 \\
2.50 & 92.0 & 102.3 & 97.2 \\
5.00 & 80.5 & 100.5 & 82.4 \\
5.00 & 82.7 & 102.9 & 79.1 \\
5.00 & 82.1 & 101.7 & 80.7 \\
\hline
\end{tabular}

The recoveries of the cocaine ranges were not appropriate in saliva but the others were shown good accuracy for LC-MS/MS method. The RSDs were less than $8.0 \%$, thus representing the good reliability and accuracy of the method as it can be seen SM-2. In addition, some ruggedness and robustness method validation parameters were given in SM-2 for proposed method.

\section{Selectivity of the analytical methods}

Solvents, saliva and urine solutions which are used during analysis were injected under same instrument conditions and any peak was monitored at the same retention time with Cocaine and BE. This shows that suitability of HPLC and LC-MS/MS methods in terms of selectivity and there are no interferences from solvents and solution.

\section{CONCLUSION}

As a result of this study, it can be claimed that liquid chromatographic techniques could be a good alternative for the analyses of various biological matrices in forensic studies. Practical, quick, precise, and accurate, reproducible analytical methods have been developed and validated for cocaine and BE. Reliable of HPLC method was shown by using LC-MS/MS method as a confirmation analysis. Also the matrices and concentrations were determined by HPLC instrument could be used, where necessary, according to SAMSHA cut off values. In the future studies, extraction procedure would be experienced to increase recovery of saliva matrix. 
Gumus et al., JOTCSA. 2016;3(3): 535-550.

RESEARCH ARTICLE

\section{ACKNOWLEDGMENTS}

This work was funded by Republic of Turkey Small and Medium Enterprises Development Organization (KOSGEB) and Industrial Thesis Support Program (SAN-TEZ) of Republic of Turkey, Ministry of Science, Industry and Technology (Project Grant No: 0620.STZ.2014) and Republic of Turkey, Ministry of Development (Project Grant No: 2016K121190). And also, this study was partially supported by Ege University Scientific Research Projects (15-FEN-020).

\section{REFERENCES}

1. National Institute on Drug Abuse (NIH), Research Report Series, 2013, Cocaine, www.drugabuse.gov

2. National Institute on Drug Abuse (NIH), Drug Facts,2013, Cocaine, www.drugabuse.gov

3. Guler E., Bozokalfa G., Demir B., Gumus ZP., Guler B., Aldemir E., Timur S., Coskunol H., 'An Aptamer Folding based Sensory Platform' Decorated with Nanoparticles for Simple Cocaine Testing, Drug Testing and Analysis 2016 Jun, doi: 10.1002/dta.1992

4. Donald G. Barceloux Robert B. Palmer (Editor), Medical Toxicology of Drug Abuse, Synthesized Chemicals and Psychoactive Plants, 2012, Wiley, 805-885 p. ISBN: 978-0-471-72760-6

5. Mackey-Bojack S., Kioss J., Apple F. Cocaine, cocaine metabolite, and ethanol concentrations in postmortem blood and vitreous humor. J. Anal. Toxicol. 2000 Jan/Feb, 24, 59-65. URL: http://jat.oxfordjournals.org/content/24/1/59.long

6. United Nations Office on Drugs and Crime. World Drug Report. United Nations, New York, 2015. https://www.unodc.org/documents/wdr2015/World Drug Report 2015.pdf

7. European Monitoring Centre for Drugs and Drug Addiction. European drug report 2014: Trends and developments. Publications Office of the European Union, Luxembourg, 2014.

http://www.emcdda.europa.eu/system/files/publications/963/TDAT14001ENN.pdf

8. Kolbrich EA., Barnes AJ., Gorelick DA., Boyd SJ., Cone EJ., and Huesfis MA. Major and Minor Metabolites of Cocaine in Human Plasma following Controlled Subcutaneous Cocaine Administration, J. Anal. Toxicol, 2006 Oct, 30, 501-510. URL: http://jat.oxfordjournals.org/content/30/8/501.long

9. Cone EJ, Tsadik A, Oyler J, Darwin WD. Cocaine metabolism and urinary excretion after different routes of administration. Therapeutic Drug Monitoring 1998 Oct; 20(5), 556 - 560. URL: http://journals. Iww.com/drugmonitoring/Abstract/1998/10000/Cocaine_Metabolism_and_Urinary_Excretion_After.19.aspx.

10. Bozokalfa, G, Akbulut, H; Demir, B, Guler, E, Gumus, ZP, Odaci Demirkol, D, Aldemir, E, Yamada, S, Endo, T, Coskunol, H, Timur, S, Yagci, Y. A polypeptide functional surface for the aptamer immobilization: Electrochemical cocaine bio-sensing, Analytical Chemistry, 2016 Mar, 88(7), 41614167. DOI: http://dx.doi.org/10.1021/acs.analchem.6b00760

11. Hiemke C. Baumann P. Bergemann N. Conca A. Dietmaier O. Egberts K. et al. The AGNP Consensus Guidelines for Therapeutic Drug Monitoring in Psychiatry: Update 2011, Pharmacopsychiatry, 2011, 44 (06), 195-235. DOI: $10.1055 / \mathrm{s}-0031-1286287$

12. Urine drug testing in the management of chronic pain. URL:

https://www.drugabuse.gov/sites/default/files/files/UrineDrugTesting.pdf. 
13. Gourlay DL Heit HA. Caplan, YH. Urine Drug Testing in Clinical Practice. 2010, 1-24. URL: http://www.pharmacomgroup.com/udt/udt5.pdf

14. Analytes and Their Cutoffs, 2010, URL:

http://www.samhsa.gov/sites/default/files/workplace/2010GuidelinesAnalytesCutoffs.pdf

15. Wilsenach, JA.; Schuurbiers, CAH.; Van Loosdrecht, MCM. Phosphate and Potassium Recovery from Source Seperated Urine through Struvite Preparation. Water Research. 2007, 41, 458-466. DOI: http://dx.doi.org/10.1016/j.watres.2006.10.014.

16. Gal, JY.; Fovet, Y.; Adib-Yadzi, M. About a Synthetic Saliva for in vitro Studies. Talanta 2001 Mar, 53 (6), 1103-1115. DOI: http://dx.doi.org/10.1016/S0039-9140(00)00618-4.

17. Bahadır EB., Sezgintürk MK., A comparative study of short chain and long chain mercapto acids used in biosensor fabrication: A VEGF-R1-based immunosensor as a model system. Artificial Cells, Nanomedicine, and Biotechnology, 2016, 44(2), 462-470. DOI: 10.3109/21691401.2014.962743

18. 18.ICH, International Conference on Harmonization Guidelines (ICH Q2B, validation of analytical procedures, methodology). http://www.ich.org/products/guidelines/quality/qualitysingle/article/validation-of-analytical-procedures-text-and-methodology.html 
Gumus et al., JOTCSA. 2016;3(3): 535-550.

RESEARCH ARTICLE

Türkçe Öz ve Anahtar Kelimeler

\section{Biyolojik Ortamlarda Kokain ve Benzoilekgoninin HPLC ve LC-MS/MS}

\section{ile Analizi}

Öz: Yasadışı ve bağımlılık yapan bir kimyasal olan kokainin kötüye kullanımı ve bu ilaca olan bağımlııı dünya çapında artmaya devam etmektedir. Birçok analitik test kokainin idrardaki ana metaboliti olan benzoilekgoninin idrar içersinde analizine yöneliktir. Bu çalışmada kokainin idarar ve kandaki analizinin yanısıra tükürükte de analizi gerçekleştirilmiştir. Kokain ve benzoilekgonin için pratik, hızlı, güvenilir, kesin, doğru ve tekrarüretilebilir metotlar geliştirilmiş ve valide edilmiştir. Ayrıca, bu kromatografik teknikler hem başlangıç hem de doğrulayıcı testler olarak uygulanmıştır. Valide edilmiş olan kromatografik metotlar sentetik ortamlar içerisindeki kokain ve benzoilekgonin bileşiklerine başarılı bir şekilde uygulanmıştır. Doğrulama analizleri HPLC sonuçlarını desteklemek amacıyla LC-MS/MS cihazında yapılmıştır. Sonuç olarak, birçok matriks için uygulanan adli çalışmalarda HPLC'nin iyi bir alternatif olduğu gösterilmiştir.

Anahtar Kelimeler: Kokain; Benzoilekgonin; HPLC; LC-MS/MS. 
